\title{
Genetic diversity of Imjin virus in the Ussuri white-toothed shrew (Crocidura lasiura) in the Republic of Korea, 2004-2010
}

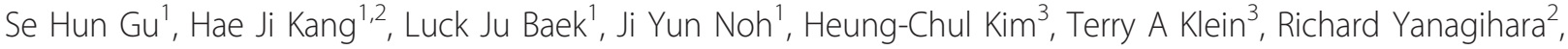 \\ Jin-Won Song ${ }^{1 *}$
}

\begin{abstract}
Recently, Imjin virus (MJNV), a genetically distinct hantavirus, was isolated from lung tissues of the Ussuri whitetoothed shrew (Crocidura lasiura) captured near the demilitarized zone in the Republic of Korea. To clarify the genetic diversity of MJNV, partial M- and L-segment sequences were amplified from lung tissues of 12 of 37 (32.4\%) anti-MJNV IgG antibody-positive Ussuri white-toothed shrews captured between 2004 and 2010. A 531-nucleotide region of the $\mathrm{M}$ segment (coordinates 2,255 to 2,785) revealed that the $12 \mathrm{MJNV}$ strains differed by $0-12.2 \%$ and $0-2.3 \%$ at the nucleotide and amino acid levels, respectively. A similar degree of nucleotide (0.2-11.9\%) and amino acid (0-3.8\%) difference was found in a 632-nucleotide length of the $L$ segment (coordinates 962 to 1,593) of nine MJNV strains. Phylogenetic analyses, based on the partial $M$ and $L$ segments of MJNV strains generated by the neighbor-joining and maximum likelihood methods, showed geographic-specific clustering, akin to the phylogeography of rodent-borne hantaviruses.
\end{abstract}

\section{Findings}

Genetically distinct hantaviruses have been discovered recently in several species of shrews (Order Soricomorpha, Family Soricidae) across four continents, including the Eurasian common shrew (Sorex araneus) [1], Chinese mole shrew (Anourosorex squamipes) [2], Therese's shrew (Crocidura theresae) [3], masked shrew (Sorex cinereus) [4], dusky shrew (Sorex monticolus) [4], northern short-tailed shrew (Blarina brevicauda) [5] and flat-skulled shrew (Sorex roboratus) [6]. Also, a novel hantavirus, named Imjin virus (MJNV), has been isolated from tissues of the Ussuri white-toothed shrew (Crocidura lasiura) captured in the Republic of Korea [7]. As demonstrated recently, Seewis virus (SWSV) harbored by the Eurasian common shrew throughout its broad geographic range exhibits geographic-specific genetic variation, similar to the phylogeography of rodent-borne hantaviruses $[8,9]$. A U.S. Army surveillance program, aimed at monitoring the prevalence of Hantaan virus (HTNV) infection in

\footnotetext{
* Correspondence: jwsong@korea.ac.kr

'Department of Microbiology, College of Medicine, and Institute for Viral Diseases, Korea University, 5-ga, Anam-dong, Sungbuk-gu, Seoul 136-705, Korea

Full list of author information is available at the end of the article
}

striped field mouse (Apodemus agrarius) populations near the demilitarized zone (DMZ) in Korea, provided an opportunity to investigate the genetic diversity and phylogeography of MJNV in the crocidurine shrew species reservoir.

A total of 466 Ussuri white-toothed shrews were live caught in multiple sites, located 30 to 370 kilometers from Seoul, during March 2004 to May 2010 (Figure 1): Paju City, Yeoncheon-gun, Pocheon City, Dongducheon City, Yangpyeong-gun, Osan City, Suwon City and Pyeongtaek City in Gyeonggi province; Sincheorwongun and Pyeongchang-gun in Gangwon province; Gunsan City in Jeollabuk province; and Haenam-gun in Jeollanam province [10-12]. Sera collected from C. lasiura were initially diluted $1: 32$ in phosphate buffered saline and examined for IgG antibodies against MJNV, using the indirect immunofluorescent antibody (IFA) test [7]. In the absence of a crocidurine shrew species-specific secondary antibody, an equal mixture of fluorescein isothiocyanate-conjugated goat anti-mouse and rat IgG (ICN Pharmaceuticals, Inc., Aurora, OH) was employed.

\section{Biomed Central}




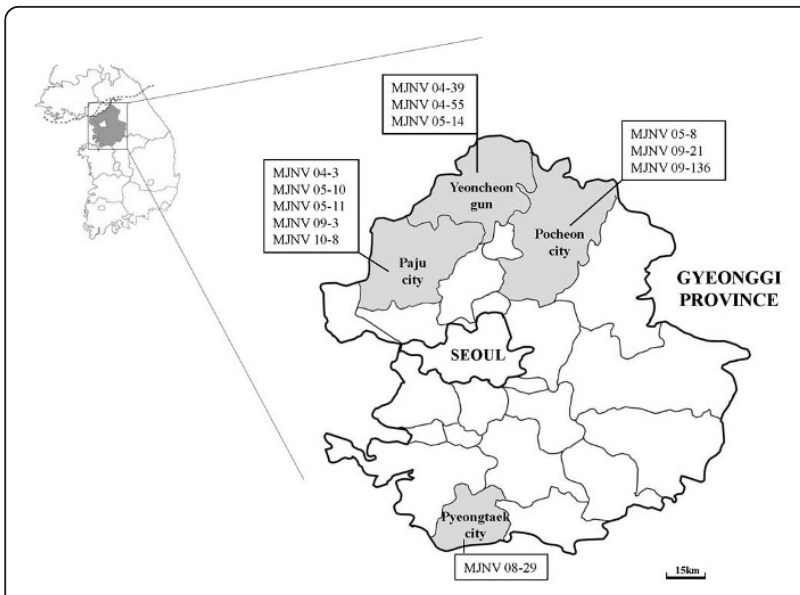

Figure 1 Map of Paju City, Yeoncheon County, and Pocheon City near the DMZ, showing the locations of the trap sites in Gyeonggi province. MJNV RT-PCR-positive Ussuri shrews (boxes) were trapped in three cities and/or counties (gun), in the Republic of Korea during 2004-2010.

Total RNA was extracted from lung tissues of antiMJNV IgG antibody-positive shrews, using the RNA$\mathrm{Bee}^{\mathrm{TM}}$ isolation kit (TEL-TEST, Inc., Friendswood, TX), and reverse transcribed, using M-MLV reverse transcriptase (Promega, Madison, WI) and a universal primer (OSM55: 5'-TAGTAGTAGACTCC-3'). Polymerase chain reaction (PCR) was performed in $50-\mu \mathrm{L}$ mixtures, containing $200 \mu \mathrm{M}$ dNTP, $0.5 \mathrm{U}$ of SuperTherm Taq DNA polymerase (JMR Holdings, London, $\mathrm{UK}), 1 \mu \mathrm{g}$ of cDNA and $5 \mathrm{pM}$ of each primer. Oligonucleotide primer sequences for nested PCR were MJN-M2235F: 5'-CATGGAAGAGTGCAACATGT-3' and MJN-M2855R: 5'-TATGGTCCCTAGATGTACT3', MJV-M2235F and MJN-M2805R: 5'-TCTATAAT AGGATCAGTCAT-3' for the M segment; MJN-L942F: 5'-TCAGAATATAAACCTATGAC-3' MJN-L1636R: 5'GATCAACAAACCCATATC-3', then MJN-L942F and MJN-L1612R: 5'-CTTACATGAGCAGTGGCTA-3' for the $\mathrm{L}$ segment. Initial denaturation was at $94^{\circ} \mathrm{C}$ for 5 min, followed by 15 cycles of denaturation at $94^{\circ} \mathrm{C}$ for $40 \mathrm{sec}$, annealing at $50^{\circ} \mathrm{C}$ for $40 \mathrm{sec}$, elongation at $72^{\circ} \mathrm{C}$ for $1 \mathrm{~min}$, then 25 cycles of denaturation at $94^{\circ} \mathrm{C}$ for $40 \mathrm{sec}$, annealing at $52^{\circ} \mathrm{C}$ for $40 \mathrm{sec}$ and elongation at $72^{\circ} \mathrm{C}$ for $1 \mathrm{~min}$, in a Mastercycler ep gradient $\mathrm{S}$ (Eppendorf AG, Hamburg, Germany).

PCR products were purified by the QIAquick PCR Purification Kit (QIAGEN Inc., Chatsworth, CA), and DNA sequencing was performed in both directions of each PCR product, using the Big-Dye ${ }^{\circledR}$ Terminator v3.1 cycle sequencing kit (Applied Biosystems, Foster City, CA) on an automated sequencer (Model 3730, Applied Biosystems, Foster City, CA) [1,13]. For phylogenetic analysis, the neighbor-joining (N-J), maximum likelihood and MrBayes methods were employed [14]. Genetic distances were computed by PAUP (Phylogenetic Analysis Using Parsimony, version 4.0b), and topologies were evaluated by bootstrap analysis of 1,000 iterations [14].

Host identification of shrews infected with MJNV was confirmed by amplification and sequencing of the cytochrome $b$ gene of mitochondrial DNA (mtDNA) using previously described universal primers $[7,15]$.

Sera from 37 of 466 (7.9\%) Ussuri white-toothed shrews contained IgG antibodies against MJNV by the IFA test (Table 1). Of 242 male and 224 female Ussuri shrews, anti-MJNV IgG antibodies were found in sera of 20 males $(8.3 \%)$ and 17 females (7.5\%). Infection rates in shrews from the northern part of Gyeonggi province (Paju City: 10.7\%, 6/56; Yeoncheon-gun: 19.4\%, 14/72; Pocheon City: $6.9 \%, 9 / 130)$ were higher than rates in the southern part (Yangpyeong-gun: 0\%, 0/1; Osan City: 0\%, 0/2; Suwon City: 0\%, 0/1; and Pyeongtaek City: 4.5\%, $8 / 179)$. No seropositive shrews were captured in Sincheorwon-gun $(0 \%, 0 / 7)$ and Pyeongchang-gun $(0 \%, 0 / 1)$ in Gangwon province; Gunsan City $(0 \%, 0 / 2)$ in Jeollabuk province; and Haenam-gun $(0 \%, 0 / 10)$ in Jeollanam province.

Of the 37 anti-MJNV IgG antibody-positive Ussuri shrews, MJNV RNA was detected in 12 (nine males and three females) by RT-PCR. This difference in genderspecific prevalence was not statistically significant (Fisher's exact test $\mathrm{P}=0.09$ ), possibly because of the small sample size of infected shrews. However, the higher proportion of MJNV RNA-positive male shrews was reminiscent of the over-representation of hantavirus infection in male Norway rats [16], male deer mice $[17,18]$, and male marsh rice rats [19].

All 12 MJNV strains were detected in shrews captured in Gyeonggi province: five in Paju City (04-3, 05-10, 05-11, 09-3, 10-8), three in Yeoncheon-gun (04-39, 04-55, 05-14), three in Pocheon City (05-8, 09-21, 09136), and one in Pyeongtaek City (08-29) (Figure 1, Table 2). Prevalence of MJNV infection, as determined by IFA and RT-PCR, was highest during the summer and spring, respectively (Figure 2), but only a few shrews

Table 1 Prevalence of MJNV infection among Crocidura lasiura captured in the Republic of Korea, 2004-2010

\begin{tabular}{cccc}
\hline Trapping year & No. trapped & No. seropositive (\%) & RT-PCR (\%) \\
\hline 2004 & 74 & $11(14.9)$ & $3(27.3)$ \\
2005 & 41 & $7(17.1)$ & $4(57.1)$ \\
2006 & 13 & 0 & 0 \\
2007 & 41 & $4(9.8)$ & 0 \\
2008 & 100 & $5(5.0)$ & $1(20.0)$ \\
2009 & 185 & $9(4.9)$ & $3(33.3)$ \\
2010 & 12 & $1(8.3)$ & $1(100)$ \\
\hline Total & 466 & $37(7.9)$ & $12(32.4)$ \\
\hline
\end{tabular}


were captured during the summer compared to other seasons.

Overall genetic analysis of a 531-nucleotide region (coordinates 2,255 to 2,785) of the Gc glycoprotein-encoding $\mathrm{M}$ segment revealed that MJNV strains from Korea differed by $0-12.2 \%$. However, the amino acid sequences were highly conserved (0-2.3\%) (Table 3$)$. This degree of genetic diversity was higher than that of HTNV strains among striped field mice in Korea [20]. In a 632-nucleotide region of the L segment (coordinates 962 to 1,593), MJNV strains differed by $0.2-11.9 \%$ and $0-3.8 \%$ at the nucleotide and amino acid levels, respectively (Table 4). This level of interstrain difference for the MJNV L segment was similar with that of SWSV strains in Eurasian common shrews from Russia [9]. The genetic distance between MJNV strains and other crocidurine and soricine shrew-borne hantaviruses, including Thottapalayam virus (TPMV) and Cao Bang virus (CBNV), based on the M segment was 26.9 to $42.2 \%$ and 16.9 to $50.8 \%$ at the nucleotide and amino acid levels, respectively, and the nucleotide and amino acid distance based on the $\mathrm{L}$ segment was 28.5 to $50.5 \%$ and 31.9 to $61.0 \%$, respectively.

Phylogenetic analyses of partial L-segment sequences of MJNV strains, using the N-J, maximum likelihood and Bayesian methods, showed geographic-specific genetic variation (Figure 3). In the N-J tree based on the M segment, MJNV strain 04-39 from Yeoncheon-gun, Gyeonggi province, was the most divergent. This was similar to the phylogeography of rodent-borne hantaviruses, including HTNV in Apodemus agrarius [20], Soochong virus in Apodemus peninsulae [13], Puumala virus in Myodes glareolus [21,22], Muju virus in Myodes regulus [23] and Tula virus in Microtus arvalis [24]. Moreover, as recently shown for

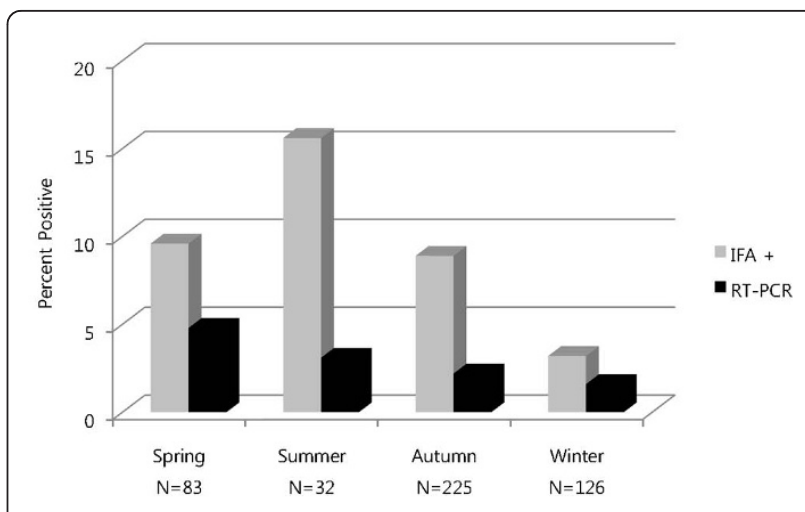

Figure 2 Comparative seasonal seroprevalence of MJNV infection, as determined by IFA and RT-PCR, in Crocidura lasiura captured in the Republic of Korea during the spring, summer, autumn and winter of 2004-2010.

SWSV in Sorex araneus [8,9], the geographic-specific genetic variation of MJNV suggested a long-standing virus-host relationship between MJNV and C. lasiura, with local host-specific adaptation.

Genetic studies of MJNV in Ussuri white-toothed shrews captured beyond Korea, in northern China and far eastern Russia, are warranted to further explore if host sharing exists for MJNV among sympatric and syntopic crocidurine shrews. Also, future research on the genetic diversity of other hantaviruses harbored by shrew species that have broad geographic distributions (such as prototype TPMV carried by the Asian house shrew) might provide additional insights into the phylogeography and evolutionary history of hantaviruses and their soricid hosts.

Table 2 MJNV strains detected in Crocidura lasiura in the Republic of Korea

\begin{tabular}{|c|c|c|c|c|}
\hline \multirow[t]{2}{*}{ MJNV strain } & \multirow[t]{2}{*}{ Trapping site } & \multirow[t]{2}{*}{ Trapping date } & \multicolumn{2}{|c|}{ GenBank accession no. } \\
\hline & & & M segment & L segment \\
\hline $04-3$ & Dagmar North 2-9/Paju, Gyeonggi & Mar 24, 2004 & EF641797† & HQ201409* \\
\hline 04-39 & LTA 130-1a/Yeoncheon, Gyeonggi & Dec 4, 2004 & EF641802† & HQ201410* \\
\hline $04-55$ & FP131A-1a/Yeoncheon, Gyeonggi & Dec 7, 2004 & EF641799† & EF641807† \\
\hline $05-8$ & MPRC-7a/Pocheon, Gyeonggi & Sep 10, 2005 & EF641800† & HQ201411* \\
\hline $05-10$ & Dagmar North-7a/Paju, Gyeonggi & Sep 12, 2005 & EF641801† & ND \\
\hline 05-11 & Story Impact-11a/Paju, Gyeonggi & Sep 14, 2005 & EF641798† & EF641806† \\
\hline $05-14$ & LTA 320/Yeoncheon, Gyeonggi & Nov 9, 2005 & EF641803† & HQ201412* \\
\hline $08-29$ & CP Humphrey/Pyeongtaek, Gyeonggi & Apr 2, 2008 & HQ201404* & ND \\
\hline $09-21$ & Nightmare Range/Pocheon, Gyeonggi & Jun 24, 2009 & HQ201405* & ND \\
\hline $09-136$ & Nightmare Range/Pocheon, Gyeonggi & Oct 28, 2009 & HQ201406* & HQ201413* \\
\hline $09-3$ & Maji-ri/Paju, Gyeonggi & Apr 17, 2009 & HQ201407* & HQ201414* \\
\hline $10-8$ & Dragon Head/Paju, Gyeonggi & May 12, 2010 & HQ201408* & HQ201415* \\
\hline
\end{tabular}

ND, not determined because of insufficient sequence data.

* The GenBank accession numbers (HQ201404-HQ201415) for the MJNV sequences determined in this study.

† The reference sequence (Song et al.) [7]. 
Table 3 Percent nucleotide and amino acid sequence similarities of partial $M$ segment of MJNV* compared with other hantaviruses

\begin{tabular}{|c|c|c|c|c|c|c|c|c|c|c|c|c|c|c|c|c|c|c|}
\hline Strain & $\begin{array}{l}\text { MJN } \\
04-3\end{array}$ & $\begin{array}{c}\text { MJN } \\
04-39\end{array}$ & $\begin{array}{l}\text { MJNV } \\
04-55\end{array}$ & $\begin{array}{l}\text { MJN } \\
05-8\end{array}$ & $\begin{array}{c}\text { MJN } \\
05-10\end{array}$ & $\begin{array}{c}\text { MJN } \\
05-11\end{array}$ & $\begin{array}{c}\text { MJN } \\
05-14\end{array}$ & $\begin{array}{c}\text { MJN } \\
08-29\end{array}$ & $\begin{array}{l}\text { MJN } \\
09-3\end{array}$ & $\begin{array}{c}\text { MJN } \\
09-21\end{array}$ & $\begin{array}{c}\text { MJN } \\
09-136\end{array}$ & $\begin{array}{l}\text { MJN } \\
10-8\end{array}$ & TPM & CBN & HTN & SEO & PUU & SN \\
\hline MJN 04-3 & & 88.4 & 98.5 & 98.7 & 100 & 98.5 & 98.5 & 98.3 & 98.5 & 98.1 & 98.1 & 99.4 & 73.1 & 58.9 & 58.4 & 58.9 & 60.2 & 58.9 \\
\hline $\begin{array}{l}\text { MJN 04- } \\
39\end{array}$ & 98.3 & & 88.1 & 88.1 & 88.3 & 88.1 & 88.1 & 87.9 & 88.1 & 87.8 & 87.8 & 88.5 & 72.5 & 59.1 & 58.1 & 57.6 & 60.6 & 61.2 \\
\hline $\begin{array}{l}\text { MJNV 04- } \\
55\end{array}$ & 100 & 98.3 & & 98.7 & 98.5 & 100 & 100 & 99.8 & 100 & 98.1 & 98.1 & 98.7 & 72.5 & 59.3 & 58.6 & 59.7 & 60.6 & 58.9 \\
\hline MJN 05-8 & 100 & 98.3 & 100 & & 98.7 & 98.7 & 98.7 & 98.5 & 98.7 & 98.3 & 98.3 & 98.9 & 72.5 & 58.9 & 58.2 & 59.1 & 59.6 & 58.9 \\
\hline $\begin{array}{l}\text { MJN 05- } \\
10\end{array}$ & 100 & 98.3 & 100 & 100 & & 98.5 & 98.5 & 98.3 & 98.5 & 98.1 & 98.1 & 99.4 & 73.1 & 58.9 & 58.4 & 58.9 & 60.2 & 58.9 \\
\hline $\begin{array}{l}\text { MJN 05- } \\
11\end{array}$ & 100 & 98.3 & 100 & 100 & 100 & & 100 & 99.8 & 100 & 98.1 & 98.1 & 98.7 & 72.5 & 59.3 & 58.6 & 59.7 & 60.6 & 58.9 \\
\hline $\begin{array}{l}\text { MJN 05- } \\
14\end{array}$ & 99.4 & 97.7 & 100 & 100 & 100 & 100 & & 99.8 & 100 & 98.1 & 98.1 & 98.7 & 72.5 & 59.3 & 58.6 & 59.7 & 60.6 & 58.9 \\
\hline $\begin{array}{l}\text { MJN 08- } \\
29\end{array}$ & 100 & 98.3 & 99.4 & 99.4 & 99.4 & 99.4 & 99.4 & & 99.8 & 97.9 & 97.9 & 98.5 & 72.3 & 59.1 & 58.4 & 59.5 & 60.4 & 58.7 \\
\hline MJN 09-3 & 100 & 98.3 & 100 & 100 & 100 & 100 & 100 & 99.4 & & 98.1 & 98.1 & 98.7 & 72.5 & 59.3 & 58.6 & 59.7 & 60.6 & 58.9 \\
\hline $\begin{array}{l}\text { MJN 09- } \\
21\end{array}$ & 99.4 & 97.7 & 99.4 & 99.4 & 99.4 & 99.4 & 99.4 & 98.9 & 99.4 & & 100 & 98.3 & 72.3 & 58.4 & 57.8 & 58.6 & 59.5 & 58.5 \\
\hline $\begin{array}{l}\text { MJN 09- } \\
136\end{array}$ & 99.4 & 97.7 & 99.4 & 99.4 & 99.4 & 99.4 & 99.4 & 98.9 & 99.4 & 100 & & 98.3 & 72.3 & 58.4 & 57.8 & 58.9 & 59.5 & 58.5 \\
\hline MJN 10-8 & 100 & 98.3 & 100 & 100 & 100 & 100 & 100 & 99.4 & 100 & 99.4 & 99.4 & & 72.7 & 58.8 & 58.2 & 58.8 & 60.0 & 59.2 \\
\hline TPM & 82.5 & 83.1 & 82.5 & 82.5 & 82.5 & 82.5 & 82.5 & 81.9 & 82.5 & 81.9 & 81.9 & 82.5 & & 57.8 & 56.9 & 58.8 & 60.2 & 57.0 \\
\hline CBN & 49.7 & 49.2 & 49.7 & 49.7 & 49.7 & 49.7 & 49.7 & 49.2 & 49.7 & 49.2 & 49.2 & 49.7 & 52.0 & & 67.4 & 69.7 & 66.1 & 65.3 \\
\hline HTN & 53.7 & 53.1 & 53.7 & 53.7 & 53.7 & 53.7 & 53.7 & 53.1 & 53.7 & 53.1 & 53.1 & 53.7 & 53.7 & 71.8 & & 76.3 & 68.0 & 65.0 \\
\hline SEO & 52.5 & 52.0 & 52.5 & 52.5 & 52.5 & 52.5 & 52.5 & 52.0 & 52.5 & 52.0 & 52.0 & 52.5 & 53.1 & 71.8 & 83.1 & & 67.2 & 62.3 \\
\hline PUU & 59.1 & 58.5 & 59.1 & 59.1 & 59.1 & 59.1 & 59.1 & 58.5 & 59.1 & 58.5 & 58.5 & 59.1 & 55.7 & 64.8 & 67.0 & 67.0 & & 71.8 \\
\hline SN & 55.1 & 54.5 & 55.1 & 55.1 & 55.1 & 55.1 & 55.1 & 55.1 & 55.1 & 54.5 & 54.5 & 55.1 & 54.0 & 67.6 & 68.2 & 65.3 & 69.0 & \\
\hline
\end{tabular}

*MJNV strains 04-3, 05-10, 05-11, 09-3, 10-8 from Paju City; MJNV strains 04-39, 04-55, 05-14 from Yeoncheon-gun; MJNV strains 05-8, 09-21, 09-136 from Pocheon City; MJN strain 08-29 from Pyeongtaek City.

Amino acid similarity shown on bottom triangle and nucleotide similarity shown on top triangle.

Table 4 Percent nucleotide and amino acid sequence similarities of partial L segment of MJNV* compared with other hantaviruses

\begin{tabular}{|c|c|c|c|c|c|c|c|c|c|c|c|c|c|c|c|}
\hline Strain & $\begin{array}{l}\text { MJN } \\
04-3\end{array}$ & $\begin{array}{c}\text { MJN 04- } \\
39\end{array}$ & $\begin{array}{c}\text { MJN 04- } \\
55\end{array}$ & $\begin{array}{l}\text { MJN } \\
05-8\end{array}$ & $\begin{array}{c}\text { MJN 05- } \\
11\end{array}$ & $\begin{array}{c}\text { MJN 05- } \\
14\end{array}$ & $\begin{array}{c}\text { MJN 09- } \\
21\end{array}$ & $\begin{array}{c}\text { MJN 09- } \\
136\end{array}$ & $\begin{array}{l}\text { MJN } \\
10-8\end{array}$ & TPM & SWS & HTN & SEO & PUU & SN \\
\hline MJN 04-3 & & 89.1 & 88.8 & 97.9 & 98.7 & 89.4 & 98.6 & 98.4 & 99.2 & 71.2 & 49.9 & 52.9 & 50.7 & 54.4 & 52.4 \\
\hline MJN 04-39 & 98.6 & & 98.4 & 88.9 & 88.4 & 99.4 & 88.9 & 88.8 & 88.8 & 70.2 & 51.4 & 53.4 & 51.0 & 54.8 & 54.2 \\
\hline MJN 04-55 & 97.1 & 97.6 & & 88.6 & 88.1 & 99.1 & 88.6 & 88.4 & 88.4 & 69.4 & 50.9 & 52.6 & 50.7 & 54.2 & 52.5 \\
\hline MJN 05-8 & 100 & 98.6 & 97.1 & & 97.6 & 89.2 & 98.7 & 98.9 & 97.6 & 71.2 & 51.0 & 52.6 & 51.0 & 54.4 & 52.2 \\
\hline MJN 05-11 & 99.0 & 97.6 & 96.2 & 99.0 & & 88.8 & 98.3 & 98.1 & 98.4 & 70.8 & 50.2 & 52.5 & 51.2 & 54.4 & 51.9 \\
\hline MJN 05-14 & 99.0 & 99.5 & 98.1 & 99.0 & 98.1 & & 89.2 & 89.1 & 89.1 & 71.2 & 50.2 & 53.4 & 51.0 & 55.0 & 53.0 \\
\hline MJN 09-21 & 100 & 98.6 & 97.1 & 100 & 99.0 & 99.0 & & 99.8 & 98.3 & 70.5 & 50.4 & 52.8 & 50.9 & 54.7 & 51.9 \\
\hline $\begin{array}{l}\text { MJN 09- } \\
136\end{array}$ & 100 & 98.6 & 97.1 & 100 & 99.0 & 99.0 & 100 & & 98.1 & 70.7 & 50.4 & 52.6 & 50.7 & 54.5 & 51.7 \\
\hline MJN 10-8 & 99.5 & 98.1 & 96.7 & 99.5 & 98.6 & 98.6 & 99.5 & 99.5 & & 71.5 & 50.2 & 53.1 & 50.7 & 53.9 & 52.5 \\
\hline TPM & 67.6 & 67.6 & 66.7 & 67.6 & 67.6 & 68.1 & 67.6 & 67.6 & 67.1 & & 50.5 & 51.7 & 50.9 & 55.2 & 52.8 \\
\hline SWS & 39.5 & 40.5 & 39.0 & 39.5 & 39.5 & 40.0 & 39.5 & 39.5 & 39.5 & 62.2 & & 63.2 & 61.5 & 56.8 & 58.7 \\
\hline HTN & 42.9 & 42.4 & 41.9 & 42.9 & 42.4 & 42.9 & 42.9 & 42.9 & 42.9 & 43.1 & 55.9 & & 70.2 & 58.2 & 57.6 \\
\hline SEO & 41.0 & 41.0 & 40.0 & 41.0 & 40.5 & 41.0 & 41.0 & 41.0 & 41.0 & 38.4 & 58.2 & 77.9 & & 58.2 & 59.3 \\
\hline PUU & 45.7 & 45.2 & 44.8 & 45.7 & 45.7 & 45.7 & 45.7 & 45.7 & 45.2 & 46.4 & 53.1 & 54.0 & 77.9 & & 64.6 \\
\hline SN & 45.7 & 46.7 & 45.2 & 45.7 & 45.7 & 46.2 & 45.7 & 45.7 & 45.7 & 46.4 & 54.9 & 54.5 & 55.4 & 64.8 & \\
\hline
\end{tabular}

*MJNV strains 04-3, 05-11, 10-8 from Paju City; MJNV strains 04-39, 04-55, 05-14 from Yeoncheon-gun; MJNV strain 05-8, 09-21, 09-136 from Pocheon City. Amino acid similarity shown on bottom triangle and nucleotide similarity shown on top triangle. 


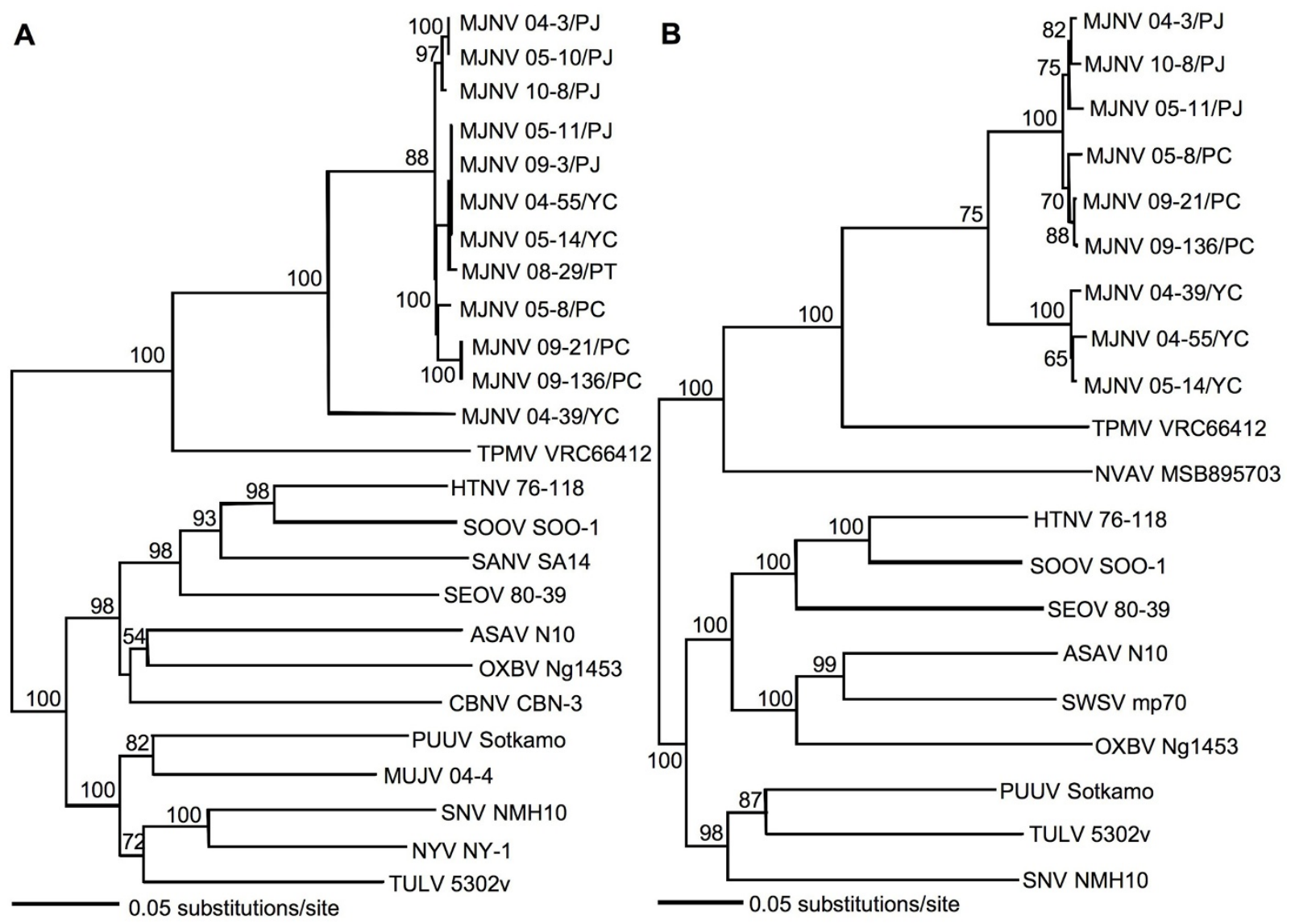

Figure 3 Phylogenetic trees generated by the neighbor-joining method using PAUP version 4.0b, based on the (A) 531-nucleotide M segment and (B) 632-nucleotide $L$ segment of MJNV strains. The phylogenetic positions of MJNV strains are shown in relationship to representative soricomorph- and rodent-borne hantaviruses, including Thottapalayam virus (TPMV VRC66412; EU001329, EU001330), Cao Bang virus (CBNV 3; EF543525, EF543526), Asama virus (ASAV N10; EU929075, EU929078), Oxbow virus (OXBV Ng1453; FJ539167, FJ593497), Seewis virus (SWSV mp70; EF636026), Nova virus (NVAV MSB95703; FJ593498), Hantaan virus A(HTNV 76-118; NC_005219, NC_005222), Soochong virus (SOOV SOO-1; AY675353, DQ056292), Sangassou virus (SANV SA14; DQ268651), Seoul virus (SEOV 80-39; NC_005237, NC_005238), Puumala virus (PUUV Sotkamo; NC_005223, NC_005225), Muju virus (MUJV 04-4, EF198413), Tula virus (TULV 5302v; NC_005228, NC_005226), New York virus (NYV NY1; U36802) and Sin Nombre virus (SNV NMH10; NC_005215, NC_005217).

\section{Acknowledgements}

This work was supported in part by U.S. Public Health Service grants from the National Institute of Allergy and Infectious Diseases (R01Al075057) and the National Center for Research Resources (P2RR018727 and G12RR003061), National Institutes of Health, and grants from the U.S Department of Defense, Global Emerging Infectious Surveillance and Response System (GEIS), and the Armed Forces Medical Intelligence Center (AFMIC).

\section{Author details}

'Department of Microbiology, College of Medicine, and Institute for Viral Diseases, Korea University, 5-ga, Anam-dong, Sungbuk-gu, Seoul 136-705, Korea. ${ }^{2}$ Departments of Pediatrics and Tropical Medicine, Medical Microbiology and Pharmacology, John A. Burns School of Medicine, University of Hawai'i at Manoa, 651 Ilalo Street, Honolulu, HI 96813, USA. ${ }^{3}$ Force Health Protection and Preventive Medicine, $65^{\text {th }}$ Medical Brigade, U.S. Army MEDDAC-Korea, Unit 15281, APO AP 96205-5281, USA.

\section{Authors' contributions}

SHG performed the RNA extraction, RT-PCR and DNA sequencing. HJK provided the preliminary sequencing data and assisted with the phylogenetic analysis. LJB, HCK and TAK arranged the field expeditions and provided the background data on wild-caught shrews. JYN performed the genetic analysis, RY arranged the collaboration and provided scientific oversight, and JWS conceived the research design, coordinated the implementation of the project, including the design of oligonucleotide primers and phylogenetic analysis. All authors read and approved the final manuscript.

\section{Competing interests}

The authors declare that they have no competing interests.

Received: 20 September 2010 Accepted: 8 February 2011 Published: 8 February 2011 


\section{References}

1. Song JW, Gu SH, Bennett SN, Arai S, Puorger M, Hilbe M, Yanagihara R: Seewis virus, a genetically distinct hantavirus in the Eurasian common shrew (Sorex araneus). Virol J 2007, 4:114.

2. Song JW, Kang HJ, Song KJ, Truong TT, Bennett SN, Arai S, Truong NU, Yanagihara R: Newfound hantavirus in Chinese mole shrew, Vietnam. Emerg Infect Dis 2007, 13:1784-1787.

3. Klempa B, Fichet-Calvet E, Lecompte E, Auste B, Aniskin V, Meisel H, Barriere P, Koivogui L, ter Meulen J, Krüger DH: Novel hantavirus sequences in shrew, Guinea. Emerg Infect Dis 2007, 13:520-522.

4. Arai S, Bennett SN, Sumibcay L, Cook JA, Song JW, Hope A, Parmenter C, Nerurkar VR, Yates TL, Yanagihara R: Phylogenetically distinct hantaviruses in the masked shrew (Sorex cinereus) and dusky shrew (Sorex monticolus) in the United States. Am J Trop Med Hyg 2008, 78:348-351.

5. Arai S, Song JW, Sumibcay L, Bennett SN, Nerurkar VR, Parmenter C, Cook JA, Yates TL, Yanagihara R: Hantavirus in northern short-tailed shrew, United States. Emerg Infect Dis 2007, 13:1420-1423.

6. Kang HJ, Arai S, Hope AG, Cook JA, Yanagihara R: Novel hantavirus in the flat-skulled shrew (Sorex roboratus). Vector Borne Zoonotic Dis 2010, 10:593-597.

7. Song JW, Kang HJ, Gu SH, Moon SS, Bennett SN, Song KJ, Baek LJ, Kim HC, O'Guinn ML, Chong ST, et al: Characterization of Imjin virus, a newly isolated hantavirus from the Ussuri white-toothed shrew (Crocidura lasiura). J Virol 2009, 83:6184-6191.

8. Kang HJ, Arai S, Hope AG, Song JW, Cook JA, Yanagihara R: Genetic diversity and phylogeography of Seewis virus in the Eurasian common shrew in Finland and Hungary. Virol J 2009, 6:208,

9. Yashina LN, Abramov SA, Gutorov W, Dupal TA, Krivopalov AV, Panov W, Danchinova GA, Vinogradov W, Luchnikova EM, Hay J, et al: Seewis virus: phylogeography of a shrew-borne hantavirus in Siberia, Russia. Vector Borne Zoonotic Dis 2010, 10:585-591.

10. O'Guinn ML, Klein TA, Lee JS, Kim HC, Baek LJ, Chong ST, Turell MJ, Burkett DA, Schuster A, Lee IY, et al: Ecological surveillance of small mammals at Firing Points 10 and 60, Gyeonggi Province, Republic of Korea, 2001-2005. J Vector Ecol 2008, 33:370-384.

11. Payne KS, Klein TA, Otto JL, Kim HC, Chong ST, Ha SJ, Gu SH, Jeong JH, Baek $L$, Song JW: Seasonal and environmental determinants of leptospirosis and scrub typhus in small mammals captured at a U.S. military training site (Dagmar North), Republic of Korea, 2001-2004. Mil Med 2009, 174:1061-1067.

12. O'Guinn ML, Klein TA, Lee JS, Richards AL, Kim HC, Ha SJ, Shim SH, Baek L, Song KJ, Chong ST, et al: Serological surveillance of scrub typhus, murine typhus, and leptospirosis in small mammals captured at firing points 10 and 60, Gyeonggi province, Republic of Korea, 2001-2005. Vector Borne Zoonotic Dis 2010, 10:125-133.

13. Baek L, Kariwa H, Lokugamage K, Yoshimatsu K, Arikawa J, Takashima I, Kang Jl, Moon SS, Chung SY, Kim EJ, et al: Soochong virus: an antigenically and genetically distinct hantavirus isolated from Apodemus peninsulae in Korea. J Med Virol 2006, 78:290-297.

14. Swofford D: PAUP*:Phylogenetic Analysis Using Parsimony (*and Other Methods) Sunderland, Massachusetts: Sinauer Associates; 2003.

15. Smith MF, Patton JL: Variation in mitochondrial cytochrome b sequence in natural populations of South American akodontine rodents (Muridae: Sigmodontinae). Mol Biol Evol 1991, 8:85-103.

16. Hinson ER, Shone SM, Zink MC, Glass GE, Klein SL: Wounding: the primary mode of Seoul virus transmission among male Norway rats. Am J Trop Med Hyg 2004, 70:310-317.

17. Calisher $\mathrm{CH}$, Root JJ, Mills JN, Rowe JE, Reeder SA, Jentes ES, Wagoner $\mathrm{K}$, Beaty BJ: Epizootiology of Sin Nombre and El Moro Canyon hantaviruses, southeastern Colorado, 1995-2000. J Wild Dis 2005, 41:1-11.

18. Douglass RJ, Wilson T, Semmens WJ, Zanto SN, Bond CW, Van Horn RC, Mills JN: Longitudinal studies of Sin Nombre virus in deer mousedominated ecosystems of Montana. Am J Trop Med Hyg 2001, 65:33-41.

19. Mclntyre NE, Chu YK, Owen RD, Abuzeineh A, De la Sancha N, Dick CW, Holsomback T, Nisbett RA, Jonsson C: A longitudinal study of Bayou virus, hosts, and habitat. Am J Trop Med Hyg 2005, 73:1043-1049.

20. Song JW, Baek LJ, Kim SH, Kho EY, Kim JH, Yanagihara R, Song KJ: Genetic diversity of Apodemus agrarius-borne hantaan virus in Korea. Virus Genes 2000, 21:227-232.

21. Plyusnin A, Vapalahti O, Lehvaslaiho H, Apekina N, Mikhailova T, Gavrilovskaya I, Laakkonen J, Niemimaa J, Henttonen H, Brummer-
Korvenkontio M, et al: Genetic variation of wild Puumala viruses within the serotype, local rodent populations and individual animal. Virus Res 1995, 38:25-41.

22. Plyusnin A, Vapalahti O, Ulfves K, Lehvaslaiho H, Apekina N, Gavrilovskaya I, Blinov V, Vaheri A: Sequences of wild Puumala virus genes show a correlation of genetic variation with geographic origin of the strains. $J$ Gen Virol 1994, 75:405-409.

23. Song KJ, Baek L, Moon S, Ha SJ, Kim SH, Park KS, Klein TA, Sames W, Kim HC, Lee JS, et al: Muju virus, a novel hantavirus harboured by the arvicolid rodent Myodes regulus in Korea. J Gen Virol 2007, 88:3121-3129.

24. Song JW, Baek LJ, Song KJ, Skrok A, Markowski J, Bratosiewicz-Wasik J, Kordek R, Liberski PP, Yanagihara R: Characterization of Tula virus from common voles (Microtus arvalis) in Poland: evidence for geographicspecific phylogenetic clustering. Virus Genes 2004, 29:239-247.

doi:10.1186/1743-422X-8-56

Cite this article as: Gu et al.: Genetic diversity of Imjin virus in the Ussuri white-toothed shrew (Crocidura lasiura) in the Republic of Korea, 2004-2010. Virology Journal 2011 8:56.

\section{Submit your next manuscript to BioMed Central and take full advantage of:}

- Convenient online submission

- Thorough peer review

- No space constraints or color figure charges

- Immediate publication on acceptance

- Inclusion in PubMed, CAS, Scopus and Google Scholar

- Research which is freely available for redistribution

Submit your manuscript at www.biomedcentral.com/submit
Ciomed Central 